OPEN ACCESS

Edited by:

Claudio Pignata

University of Naples Federico II, Italy

Reviewed by:

Cinzia Milito,

Sapienza University of Rome, Italy

Ugo Ramenghi,

University of Turin, Italy

*Correspondence:

Daniele Zama

daniele.zama@aosp.bo.it

Specialty section:

This article was submitted to

Pediatric Immunology,

a section of the journal

Frontiers in Pediatrics

Received: 03 August 2018

Accepted: 08 July 2019

Published: 23 July 2019

Citation:

Rivalta B, Zama D, Pancaldi G, Facchini E, Cantarini ME, Miniaci A, Prete A and Pession A (2019) Evans Syndrome in Childhood: Long Term

Follow-Up and the Evolution in

Primary Immunodeficiency or

Rheumatological Disease.

Front. Pediatr. 7:304

doi: 10.3389/fped.2019.00304

\section{Evans Syndrome in Childhood: Long Term Follow-Up and the Evolution in Primary Immunodeficiency or Rheumatological Disease}

\author{
Beatrice Rivalta, Daniele Zama*, Giovanni Pancaldi, Elena Facchini, Maria Elena Cantarini, \\ Angela Miniaci, Arcangelo Prete and Andrea Pession
}

Department of Pediatrics, Sant'Orsola-Malpighi Hospital, University of Bologna, Bologna, Italy

Evans syndrome (ES) is a rare but challenging condition, characterized by recurrent and refractory cytopenia episodes. Recent discoveries highlighted that an appropriate diagnostic workup is fundamental to identify an underlying immune dysregulation such as primary immunodeficiencies or a rheumatological disease. We hereby describe clinical features and laboratory results of 12 pediatric patients affected by ES referred to the Pediatric Onco-Hematology Unit of Bologna. Patients experienced a median of four acute episodes of cytopenia with 9 years as median age at the onset of symptoms. In 8/12 (67\%) patients an underlying etiology, primary immunodeficiencies, or rheumatological disease was identified. In 4/12 children, other immune manifestations were associated (Thyroiditis, Celiac disease, Psoriasis, Vitiligo, Myositis, Membranoproliferative Glomerulonephritis). ES remained the primary diagnosis in four patients (33\%). At a median follow-up time of 4 years, 5/12 (42\%) patients revealed a chronic ITP, partially responsive to second line therapy. Immunoglobulin Replacement Therapy (IRT) was effective with a good hematological values control in three patients with a secondary ES (ALPS, CVID, and a patient with Rubinstein Taybi Syndrome and a progressive severe B cell deficiency with hypogammaglobulinemia). Our experience highlights that, in pediatric patients, ES is often only the first manifestation of an immunological or rheumatological disease, especially when cytopenias are persistent or resistant to therapy, with an early-onset or when are associated with lymphadenopathy.

Keywords: Evans syndrome, immune cytopenias, children, primary immunodeficiency, autoimmune disease, rheumatological disease, refractory cytopenia, immunological characterization

\section{INTRODUCTION}

Evans Syndrome (ES) is a rare condition, first described by Evans in 1951 (1) as the association of Autoimmune Hemolytic Anemia (AIHA) and Immune Thrombocytopenia (ITP) and it was considered an idiopathic autoimmune disease. Until now different definitions for ES have been used in literature. Some authors defined ES as the presence of an autoimmune destruction of at least 2 cell lineages, while others requested the presence of AIHA and ITP regardless of autoimmune neutropenia (AIN). Others restricted diagnosis of ES only to patients with no identifiable underlying cause of AIHA with ITP $(2,3)$. Finally, there were authors considering secondary forms too $(4,5)$, most commonly primary immunodeficiencies (PID) and rheumatological disease. 
Fischer et al. reported a risk of autoimmune cytopenia 120 times higher in patients with PID than general population (6). Most frequently, in patients affected by PID, causes of ES were Common Variable Immunodeficiency (CVID) and Autoimmune Lymphoproliferative Syndrome (ALPS) $(7,8)$ whereas in rheumatological disease, Systemic Lupus Erythematosus (SLE) and Antiphospholipid Antibody Syndrome (APS) (9). For that reason, some authors considered useful screening for ALPS, CVID, SLE, and APS in children with chronic single lineage autoimmune cytopenia or multi-lineage autoimmune cytopenias and search for HIV infection in adolescents $(4,10)$. Hematological manifestations often precede the whole clinical onset of the immunodeficiency and it is only with further investigation that primary immunodeficiency is revealed. We hypothesized that recognition of an immunological background and of the cause of secondary ES could be useful to assess prognosis correctly and necessary for a proper therapeutic choice, especially regarding immunomodulators and corticosteroidsparing agents $(4,8,11)$. Although literature suggests an association of ES with primary immune dysregulation, data mainly come from small cohorts of adult patients. Considering that characteristics and outcomes of children with ES are not well-documented, this study aims to describe natural history of autoimmune multi-lineage cytopenias in children referred to our center.

\section{MATERIALS AND METHODS}

Between 2002 and 2018, 12 patients with Evans syndrome referred to the Pediatric Onco-Hematology Unit of Bologna and data regarding clinical history and immuno-autoimmune laboratory tests were retrospectively collected. Internal review board (IRB) approval was obtained at S. Orsola-Malpighi Hospital for the study. Written informed consent was previously obtained from children's parents. Population included pediatric patients (age $0-18$ at onset of cytopenia) with at least two concurrent or sequential autoimmune cytopenias (ITP, AIHA, AIN). Secondary forms were included and idiopathic ES was considered as an exclusion diagnosis. According to international working group criteria, ITP diagnosis was based on a platelet count of $<10010^{9} / \mathrm{L}$ (12). AIHA was defined as anemia $(\mathrm{Hb}<-2$ SDS $)$ and a positive direct antiglobulin test associated to signs of hemolysis (hemoglobin reductions, reticulocytosis, unconjugated hyperbilirubinemia, elevated lactate dehydrogenase, and low haptoglobin) (13). AIN was defined as an absolute neutrophil count $<1.010^{9} / \mathrm{L}$ for 6

Abbreviations: AIHA, Autoimmune Hemolytic Anemia; AIN, Autoimmune Neutropenia; ALPS, Autoimmune Lymphoproliferative Syndrome; ANA, Antinuclear Antibody; APS, Antiphospholipid Antibody Syndrome; CID, Combined Immunodeficiency; CVID, Common Variable Immunodeficiency; DNT cell, TCR $\alpha / \beta+C D 4-C D 8-$ Double Negative T cell; ES, Evans Syndrome; $\mathrm{Hb}$, Hemoglobin; IRT, Immunoglobulin Replacement Therapy; ITP, Immune Thrombocytopenia; Low-B RTS, Rubinsten Taybi Syndrome With a Progressive Severe B Cell Deficiency and Hypogammaglobulinemia; MCTD, Mixed Connective Tissue Disease; NGS, Next Generation Sequencing; PID, Primary Immunodeficiencies; SLE, Systemic Lupus Erythematosus; WES, Whole Exome Sequencing. months after exclusion of other causes (e.g., drugs, infections, or known genetic mutation) (14). In secondary ES cases, diagnosis of immuno-rheumatological disorders was made according to recent literature. CVID was defined according to revised ESID diagnostic criteria ${ }^{1}$, ALPS according to 2009 NIH International workshop (15), Mixed Connective Tissue Disease (MCTD) according to recent literature (16), and SLE according to the SLE International Collaborating Clinics classification (17, 18). For each patient demographic data, clinical presentation, underlying diagnosis, treatments, and outcome were reported (Table 1). Lymphocyte subset, immunoglobulin dosages, screening for autoantibodies, and vaccine responses (Tetanus toxoid) were always collected. When ALPS was suspected, TCR $\alpha / \beta+\mathrm{CD} 4-$ CD8- Double Negative T cell (DNT) counts and vitamin B12 levels were investigated. In vitro assessment of Fas-mediated apoptosis was performed in patients with DNT $>2.5 \%$, since it is considered a sensitive first-line screening test (19-21) (Table 2). Germline or somatic FAS mutations were tested in patients with selected ALPS clinical and laboratory features. One patient was lost after 1 year of follow up before the genetic analysis were performed. TACI mutations were investigated in children affected by CVID. Regarding severe hypogammaglobulinemia and $\mathrm{B}$ cell deficiency (with a complete lack of CD27+IgDswitched memory $\mathrm{B}$ cells and an expansion of the $\mathrm{B}$ cell subset CD21loCD38lo and CD27+IgD+ unswitched memory) of the patient with Rubinstein Taybi Syndrome, genetic analysis for mutations in BAFF-R and TACI genes were undertaken. All these gene analyses were performed by Sanger sequencing. All data were collected before the administration of immunomodulant therapies or after suspension for at least 3 months. For patients with secondary forms, data were acquired at the time of diagnosis.

\section{RESULTS}

Data of 12 patients with ES, seven females (58\%) and five males (42\%), referred to the Pediatric Onco-Hematology Unit of Bologna between 2002 and 2018 were retrospectively collected (Table 1). Median age at onset of cytopenias was 9 years (range 2-15 years) and median follow-up time was 4 years (range 117 years). At presentation multiple cytopenias were found in five children (42\%). A girl was diagnosed with AIHA, ITP, and AIN, three children with AIHA and ITP and two with ITP and AIN. In 7 patients (58\%), a second cytopenia developed only afterward. Five of these had primarily developed ITP and subsequently AIHA, the other two children developed ITP following AIHA or AIN. Patients experienced a median of four episodes (range 1-7), median time between acute events was 15 months (range 4 months -8 years). Six patients (50\%) presented significant hepatosplenomegaly or lymphadenopathy, three children (25\%) developed relevant infections (e.g., bronchiectasis pneumonia, tympanostomy tubes). Eight out of $12(67 \%)$ patients were diagnosed for PID or a rheumatological disorder. Five children were diagnosed with PID (42\%): three children with CVID

${ }^{1}$ https://esid.org/Media/Files/Common-Variable-Immunodeficiency-diagnosticcriteria 
TABLE 1 | Patients characteristics.

\begin{tabular}{|c|c|c|c|c|c|c|c|c|c|c|c|c|c|c|}
\hline & $\begin{array}{l}\text { Sex/ } \\
\text { Age at } \\
\text { onset }\end{array}$ & $\begin{array}{l}\text { Presenting } \\
\text { cytopenia }\end{array}$ & $\begin{array}{l}\text { Subsequent } \\
\text { cytopenia }\end{array}$ & $\begin{array}{l}N \text { of acute } \\
\text { episodes } \\
\text { (average period) }\end{array}$ & $\begin{array}{l}\text { Status at } \\
\text { FUP }\end{array}$ & $\begin{array}{l}\text { FUP } \\
\text { (years) }\end{array}$ & $\begin{array}{l}\text { Hepato } \\
\text { spleno } \\
\text { megaly }\end{array}$ & Infection & Others organs & $\begin{array}{l}\text { Diagnosis } \\
\text { (Genetics) }\end{array}$ & $\begin{array}{l}\text { Age at } \\
\text { dg }\end{array}$ & $\begin{array}{c}\text { IVIG } \\
\text { (infusions) }\end{array}$ & $\begin{array}{l}\text { Steroids } \\
\text { (cycles) }\end{array}$ & $\begin{array}{l}\text { Other } \\
\text { therapy }\end{array}$ \\
\hline 1 & $F / 12$ & ITP & AlHA & 1 & ITP & 4 & No & & $\begin{array}{l}\text { Previous inflam. } \\
\text { diarrhea }\end{array}$ & & & 1 & $\begin{array}{l}\text { Several (in } \\
\text { other hospital) }\end{array}$ & \\
\hline 2 & $\mathrm{M} / 15$ & $\mathrm{ITP}+\mathrm{AIN}$ & AlHA & $\begin{array}{l}2 \\
\text { (4 months) }\end{array}$ & - & 1 & No & & & & & 2 & & \\
\hline 3 & $F / 9$ & AlHA & ITP & $\begin{array}{l}2 \\
\text { (2 years) }\end{array}$ & Resolved & 3 & No & & & & & 1 & 2 & \\
\hline 4 & $F / 8$ & ITP, AlHA & & $\begin{array}{l}5 \\
\text { (1 years) }\end{array}$ & Resolved & 7 & Yes & & & & & 12 & 2 & MMF \\
\hline 5 & $F / 14$ & ITP & AlHA & $\begin{array}{l}5 \\
\text { (4 months) }\end{array}$ & Resolved & 4 & No & & DVT, PE, MPGN & SLE & 16 & 1 & 3 & \\
\hline 6 & $F / 14$ & ITP, AlHA & & $\begin{array}{l}4 \\
\text { (1 years) }\end{array}$ & ITP & 4 & Yes & & $\begin{array}{l}\text { Thyroiditis } \\
\text { psoriasis }\end{array}$ & MCTD & 15 & 1 & 4 & MMF \\
\hline 7 & $\mathrm{M} / 9$ & ITP & AlHA & Chronic ITP & ITP & 4 & Yes & & $\begin{array}{l}\text { Thyroiditis } \\
\text { celiac disease }\end{array}$ & $\begin{array}{l}\text { CVID (TACI } \\
\text { TNFRSF6: neg) }\end{array}$ & 13 & 2 & & \\
\hline 8 & $M / 2$ & ITP & AlHA & $\begin{array}{l}7 \\
\text { (18 months) }\end{array}$ & Resolved & 14 & Yes & $\begin{array}{l}\text { Bronchitis and } \\
\text { otitis }(\mathrm{CHL}) \text {, } \\
\text { resistant HP }\end{array}$ & Allergic asthma & $\begin{array}{l}\text { CVID (TACl, } \\
\text { TNFRSF6:neg) }\end{array}$ & 14 & 2 & 2 & IRT \\
\hline 9 & $\mathrm{M} / 8$ & ITP & AlHA & $\begin{array}{l}4 \\
\text { (6 months) }\end{array}$ & Resolved & 13 & Yes & & & $\begin{array}{l}\text { ALPS-FAS } \\
\text { (TNFRSF6 mut) }\end{array}$ & 9 & 2 & 3 & $\begin{array}{l}\text { MMF, } \\
\text { Rituximab, } \\
\text { IRT }\end{array}$ \\
\hline 10 & $M / 2$ & ITP, AlHA & & $\begin{array}{l}2 \\
\text { (8 years) }\end{array}$ & ITP & 9 & Yes & $\begin{array}{l}\text { Tympanostomy } \\
\text { tube for acute } \\
\text { otitis media }\end{array}$ & & $\begin{array}{l}\text { CVID } \\
\text { (TACI neg) }\end{array}$ & 10 & 5 & 2 & $\begin{array}{l}\text { MMF, } \\
\text { sirolimus, } \\
\text { eltrombopag }\end{array}$ \\
\hline 11 & $\mathrm{~F} / 5$ & AIN & ITP & $\begin{array}{l}6 \\
\text { (2 years) }\end{array}$ & Resolved & 17 & No & Bronchiectasis & $\begin{array}{l}\text { Rubinsten Taybi } \\
\text { Sdr. }\end{array}$ & $\begin{array}{l}\text { Low-B RTS } \\
\text { (BAFF-R mut) }\end{array}$ & 22 & 2 & 4 & IRT \\
\hline 12 & $F / 13$ & ITP, AlHA, AIN & & $\begin{array}{l}2 \\
\text { (1 month) }\end{array}$ & ITP & 2 & No & & $\begin{array}{l}\text { Vitiligo, } \\
\text { atopic dermatitis, } \\
\text { thyroiditis } \\
\text { myositis }\end{array}$ & SLE & 14 & 2 & & $\begin{array}{l}\text { Ciclosporin } \\
\text { per atopic } \\
\text { dermatitis }\end{array}$ \\
\hline
\end{tabular}

AlHA, Autoimmune hemolytic anemia; AIN, Autoimmune neutropenia; ALPS, Autoimmune Lymphoproliferative Syndrome; APS, Antiphospholipid Antibody Syndrome; CID, Combined Immunodeficiecy; CVID, Common Variable Immunodeficiency; CHL, Conductive Hearing Loss; DNT cell, TCR $\alpha$ / $+C D 4-C D 8-$ Double Negative T cell; DVT, deep vein thrombosis; HP, Helicobacter pylori; IRT, Immunoglobulin Replacement Therapy; ITP, Immune Thrombocytopenia; MCTD, Mixed Connective Tissue Disease; MMF, Mycophenolate mofetil; MPGN, Membranoproliferative Glomerulonephritis; PE, Pulmonary Embolism; SLE, Systemic Lupus Erythematosus. 
TABLE 2 | Laboratory investigation.

\begin{tabular}{|c|c|c|c|c|c|c|c|c|c|c|c|c|c|c|c|c|c|c|c|c|}
\hline & $\begin{array}{l}\mathrm{Hb} \\
\mathrm{Nadir} \\
\mathrm{g} / \mathrm{dl}\end{array}$ & $\begin{array}{c}\text { ANC } \\
\text { Nadir } \\
\mu L\end{array}$ & $\underset{\mathrm{lg} g / \mathrm{dl}}{\lg }$ & $\underset{\mathrm{mg} / \mathrm{dl}}{\lg A}$ & $\underset{\mathrm{mg} / \mathrm{dl}}{\operatorname{lgM}}$ & $\begin{array}{l}\text { WBC } \\
\mu L\end{array}$ & $\begin{array}{l}\text { Lymph } \\
\qquad \mu \mathrm{L}\end{array}$ & $\begin{array}{c}\text { CD3+ } \\
\%\end{array}$ & $\begin{array}{c}\text { CD4+ } \\
\%\end{array}$ & $\begin{array}{c}\text { CD4+ } \\
\mu L\end{array}$ & $\begin{array}{c}\text { CD8+ } \\
\%\end{array}$ & $\begin{array}{l}\text { CD4+/ } \\
\text { CD8+ }\end{array}$ & $\begin{array}{c}\text { NK } \\
\%\end{array}$ & $\begin{array}{c}\text { CD19+ } \\
\%\end{array}$ & $\begin{array}{c}\text { CD3+ } \\
\gamma+\delta+ \\
\%\end{array}$ & $\begin{array}{c}\text { CD3+ } \\
\text { DNT } \\
\%\end{array}$ & $\begin{array}{l}\text { Fas } \\
\text { activity }\end{array}$ & $\begin{array}{l}\text { Auto } \\
\text { antibodies }\end{array}$ & Vit B12 & $\begin{array}{l}\text { Vaccine } \\
\text { response }\end{array}$ \\
\hline 1 & 6.7 & & 1,087 & 105 & 130 & 11,560 & 2,231 & 76 & 49 & 1,093 & 23 & 2.13 & $2^{-}$ & 20.9 & 1.7 & 1.6 & & & 275 & \\
\hline 2 & 8.5 & 620 & 1,101 & 102 & 104 & $2,080^{-}$ & 1,248 & $84^{+}$ & $53^{+}$ & 661 & 23 & 2.30 & 4 & 10 & 3 & 2.8 & & ANA 1:160 & 855 & \\
\hline 3 & 6.2 & & 928 & 106 & 142 & 11,520 & 2,926 & $79^{+}$ & 41 & 1,200 & 34 & 1.21 & 6 & 14 & 3 & 1.5 & & & & \\
\hline 4 & 7.5 & & 1,114 & 114 & 131 & 6,340 & 2,110 & 77 & $62^{+}$ & 1,308 & 32 & 1.94 & 8.5 & $6.5^{-}$ & 2 & 1.8 & & & 268 & \\
\hline 5 & 6.9 & & 1,596 & 237 & 171 & 7,380 & 2,347 & 63 & 36 & 845 & 22 & $1.64^{+}$ & 13 & $23.5^{+}$ & & & & $\begin{array}{l}\text { ANA reflex 1:640, } \\
\text { ENA/ANA 14, } \\
\text { SS-A60+++, } \\
\text { SS-ARo52+++, } \\
\text { Ro60 } 240 \mathrm{U} / \mathrm{ml} \text {, dsDNA } \\
32 \mathrm{IU} / \mathrm{ml}, \\
\text { CLlgG } 54 \mathrm{U} / \mathrm{ml} \text {, CLIgM } 23 \\
\mathrm{U} / \mathrm{ml}\end{array}$ & 306 & \\
\hline 6 & 8.5 & & $1,807^{+}$ & 138 & 227 & 6,840 & 2,161 & $31^{-}$ & $16^{-}$ & $346^{-}$ & $12^{-}$ & 1.33 & 5 & $63^{+}$ & & & & $\begin{array}{l}\text { ANA reflex 1:640, } \\
\text { ENA/ANA 36, } \\
\text { RNP70+++, RNPA++, } \\
\text { U1RNP } 201 \mathrm{U} / \mathrm{ml}, \\
\text { Tg } 1967 \mathrm{U} / \mathrm{ml}, \text { TPO } 95 \\
\text { U/ml }\end{array}$ & 214 & \\
\hline 7 & 7.8 & & $585^{-}$ & $21^{-}$ & $37^{-}$ & 5,130 & $1,272^{-}$ & $79^{+}$ & $52^{+}$ & 661 & 23 & 2.26 & 9 & 12 & 2 & 4,2 & NEG & $\begin{array}{l}\text { Tg } 1238 \mathrm{Ul} / \mathrm{ml} \text {, } \\
\text { tTG } 126 \mathrm{U} / \mathrm{ml}\end{array}$ & 961 & No \\
\hline 8 & 8.3 & & $521^{-}$ & $21^{-}$ & $26^{-}$ & 5,730 & 2,636 & $87^{+}$ & 43 & 1,133 & 34 & 1.26 & 6 & $5^{-}$ & 2.6 & 3.6 & NEG & & 994 & No \\
\hline 9 & 7.2 & & 1,590 & $341^{+}$ & $22^{-}$ & 3,610 & 1,527 & 76 & 35 & 535 & 28 & 1.25 & 13 & 11 & 7 & 5.6 & POS & & $>2,000$ & Yes \\
\hline 10 & 6.5 & & $440^{-}$ & $55^{-}$ & $14^{-}$ & 7,150 & $1,160^{-}$ & 61 & 31 & $360^{-}$ & 26 & 1.19 & 5 & $33.3^{+}$ & 6 & 1 & & $\begin{array}{l}\text { ANAreflex 1:320, } \\
\text { ENA/ANA } 2.3 \text {, } \\
\text { Sp100+++, AMA M2 + }\end{array}$ & & Yes \\
\hline 11 & & 329 & $184^{-}$ & $6^{-}$ & $8^{-}$ & 5,820 & 2,178 & $90^{+}$ & 49 & 1,067 & 36 & 1.36 & 9 & $0.9^{-}$ & 4 & 1.6 & & & 396 & No \\
\hline 12 & 9 & 710 & 1,265 & 183 & 133 & $4,490^{-}$ & $1,440^{-}$ & 70 & 39 & 562 & $29^{-}$ & 1.34 & 8 & $20^{+}$ & 2 & 1 & & $\begin{array}{l}\text { ANA reflex 1:640, } \\
\text { ENA/ANA 6, } \\
\text { SS-A+, Ro52++, SRP } \\
++ \text {, } \\
\text { dsDNA } 21 \mathrm{lU} / \mathrm{ml} \text {, } \\
\text { CLIgM } 557 \mathrm{U} / \mathrm{ml}\end{array}$ & 588 & \\
\hline
\end{tabular}

Nadir of Hb (Hemoglobin) and ANC (Absolute Neutrophil Count) in patients with AIHA e AIN, Anti-Sm, Anti-Smith antibodies; AMA, Anti-mitochondrial antibodies; ANA, Antinuclear antibodies; CLIgG, Cardiolipin IgG; CLIgM, Cardiolipin IgM; DGP, Deamidated gliadin peptides; DNT cell, TCR $\alpha / \beta+C D 4-C D 8-$ Double Negative T cell; ENA, Extractable Nuclear Antigen Antibodies; RF, Rheumatoid factor; SRP, Signal recognition particle antibodies; tTG, Transglutaminase; Tg, Thyroglobulin; TPO, Thyroid Peroxidase; ${ }^{-}:<2 D S ;^{+}:>2 D S$ 
(25\%), one with ALPS-FAS (8\%), and one child affected by Rubinstein Taybi Syndrome had developed a progressive severe B cell deficiency with hypogammaglobulinemia related to a BAFFR mutation (low B-RTS, 8\%) (22). Three were diagnosed with a rheumatological disease (two with SLE, one with MCTD). Four children (33\%), one affected by CVID, also developed another autoimmune disorder (Thyroiditis, Celiac disease, Psoriasis, Vitiligo, Myositis, Membranoproliferative Glomerulonephritis).

Anti-platelet antibodies were detected in all the children and direct antiglobulin test was positive in $11 / 12$ (82\%). Only one child was found with anti-neutrophil antibodies (8\%). Antinuclear antibody (ANA) positivity was detected in four patients (33\%), three of which developed a rheumatological disease subsequently.

Three patients were lymphopenic (25\%) all of these were diagnosed with a secondary ES. One was lost after 1 year of follow-up. None of the patients had low rate of CD4+/CD8+ $\mathrm{T}$ cells. In four patients (33\%), a high DNT count $(\geq 2.5 \%$ CD3+ lymphocytes) was found. One of them was diagnosed with ALPS, two with CVID, and one was lost to follow-up before performing other tests. In other three patients with high DNT count a FAS-mediated apoptosis of mitogen-stimulated T cells and gene analysis for TNFRSF6 mutation by Sanger sequencing were performed. In only one child affected by ALPS, the FASinduced lymphocyte apoptosis assay resulted defective. In this patient germinal TNFRSF6 mutation G286X (c. 856G >T) not previously described was found.

TACI mutation was not detected in any patient with CVID. In a patient with low B-RTS, no TACI mutations were identified whereas it was detected the previously described BAFF-R monoallelic variant P21R (c.62C>G) (23).

B cell count was low in six patients (50\%), four of them affected by a PIDs, and high in two girls (17\%) both affected by a rheumatological disease. In six patients (50\%), altered immunoglobulin levels were found. One girl affected by MCTD showed high IgG value, meanwhile four cases of PID (three CVID, one low-B RTS) revealed low immunoglobulin levels. One patient affected by ALPS showed high IgA and low IgM. The immune responses to vaccines (Tetanus toxoid) resulted normal in child affected by ALPS and absent in low-B RTS and two CVID patients. A patient with CVID maintained protective levels of antibodies in particular against the Tetanus toxoid (with absent B memory IgD+ and switched).

Cytopenias were treated as shown in Table 1. All children received first-line treatments with IVIG or corticosteroids. Three children (23\%), all diagnosed with an underlying condition, underwent second-line therapies in order to control resistant ITP. One child affected by CVID was treated with Sirolimus and Eltrombopag with partial control of cytopenias. In a girl with MCTD, partial control of ITP and AHIA was achieved after Mycophenolate Mofetil therapy. Rituximab was effective in a child with ALPS even though he had developed a persistent hypogammaglobulinemia and is now undergoing immunoglobulin replacement therapy (IRT). In three children developing AIN, Granulocyte-colony stimulating factor therapy was not required. Two of these, one affected by LES, showed a trilinear cytopenia. Two episodes of ITP were treated with IGIV, whereas AIHA and AIN where mild and hadn't required therapies.

At a median follow-up time of 4 years (range 1-17), all 12 patients were alive. In only 7 (58\%) good control of cytopenias was achieved. Other five (42\%) revealed a chronic ITP partially responsive to second line therapy, out of these, four were diagnosed with a secondary ES. Three patients with a secondary ES (ALPS, CVID, and a patient with Rubinstein Taybi Syndrome) are undergoing immunoglobulin replacement therapy and maintained good hematological values control. Two children affected by CVID maintained protective levels of antibodies.

\section{DISCUSSION}

This study describes the clinical and laboratory history of 12 patients with ES treated in our Hospital in the last 17 years. Since 1980 (24), few studies have described the heterogeneity of presenting symptoms and the different underlying etiologies that came to light after an appropriate immune and rheumatological evaluation of children affected by multilineage cytopenias $(2,5$, 24-26). Our data highlight ES as a possible early manifestation of an underlying immune disorder, PID or rheumatological disease, especially when cytopenias are persistent-resistant to therapy, with an early-onset or when are associated with lymphadenopathy $(7,8,10,23,26-29)$. Particularly, for these patients, a proper laboratory investigation and a careful follow up is necessary to achieve a proper diagnosis. More than a half of our children with ES revealed an immune dysregulation (42\% PID, 16\% rheumatological disease). According to literature, no correlation between etiology or outcome and timing or sequencing of cytopenias presentation was found $(5,25,26,30)$. Serum vitamin B12 level was helpful in the differential diagnosis between IgG low-ALPS and DNT high-CVID (31) in two patients with hypogammaglobulinemia, lymphoproliferation, and raised DNT cell count. Our data also highlight that making a proper diagnosis is essential to ensure optimal management of therapies. For example 10 years ago, Rituximab was effective in treating cytopenias in a patient affected by ALPS but he developed a permanent hypogammaglobulinemia. In these patients other immunomodulatory therapies as mTOR inhibitors or Mycophenolate Mofetil should be preferred and splenectomy avoided for an increased risk of sepsis $(32,33)$. In our cohort these corticosteroid-sparing agents, used early in treatment, were efficient in two out of 12 patients, one affected by CVID and one by MCTD.

As described in literature, ES might be considered as a dysregulation of the immune system. Different mechanisms, both cellular and humoral immunity, are involved in the immunemediated cytopenias. Since the 80s', authors tried to describe and analyze the dysregulation of the immune system reporting a usual reduction of CD4/CD8 ratio, aberrant Th1/Th2 ratio, immunoglobulin levels alterations, IL-10 and IFN- $\gamma$ increase and TGF- $\beta$ suppression $(34,35)$.

As recently resumed by Fischer et al. (6), a combination of factor can predispose patients with PID to autoimmunity 


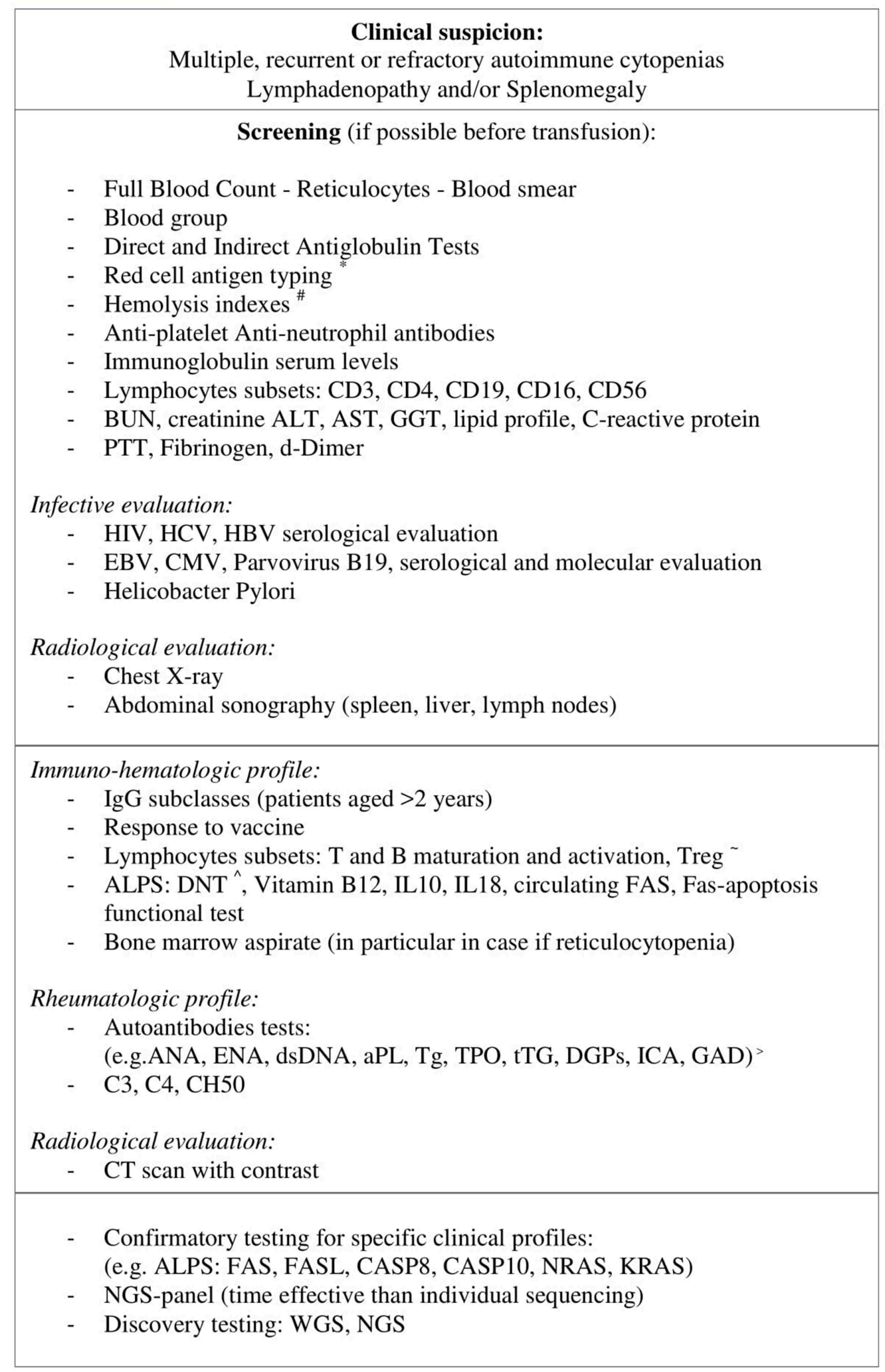

FIGURE 1 | In patients with multiple, recurrent, or refractory autoimmune cytopenias and a high clinical suspicion for an underlying disorder if general screening gives positive result further laboratory and radiological analysis should be performed. When a particular clinical suspicious is identified a specific genetic test can be done. In 
FIGURE 1 | patients with a non-specific profile, considering the declining cost and execution time of new gene sequencing techniques (NGS panel, WES, and NGS), these methodologies are likely to be more time and cost-effective than individual sequencing. *Red cell antigen typing: C, c, D, E, e, K, Jka, Jkb, Fya, Fyb, $\mathrm{S}, \mathrm{s}$, \# Hemolysis indexes: LDH, haptoglobin, bilirubin, $\sim \mathrm{T}$ and B maturation and activation: CD4/CD8 T naive (CD45RA+), CD4/CD8T memory (CD45RO), B naive (CD27-), B memory (CD27+), BCD21loCD38lo, Treg(CD4+CD25+CD127(low/-)), ^DNT: CD3+CD4-CD8-alfa/beta+, > ANA, anti-nuclear; ENA, anti-extractable nuclear antigen; aPL, anti-phospholipid; Tg, Thyroglobulin; TPO, Thyroid peroxidase; tTg, tissue transglutaminase IgA and lgG; DGPs, deamidated gliadin peptides; ICA, Autoantibodies against islet cells; GAD, Glutamic acid decarboxylase.

as a defective negative selection of self-reactive $\mathrm{T}$ and $\mathrm{B}$ cells with high affinity, defective peripheral editing of the B-cell receptor and self-antigen-induced cell death, defective regulatory $\mathrm{T}$ cells or molecules, defective clearance of immune complexes and apoptotic cell bodies, gain of function of Bor T-cell activation/effector molecules, homeostatic expansion of self-reactive T lymphocytes, exacerbated production of type I interferon or IL-1. Auto-reactive immunoglobulins could be produced due to an altered B-cell regulation during maturation and tolerance induction or by an altered T-B cells interaction. Especially IgG and rarely IgA and IgM, bound to red blood cells leading to their destruction by antibody-dependent cellular cytotoxicity and/or by the activation of the complement cascade. Neutrophils are attached by antibodies that mostly binds the IgG Fc receptor type $3 \mathrm{~b}$ (FccIIIb receptor). Also platelets could be opsonized and be prematurely removed by the reticulo-endothelial system. In ALPS, the defect of T-cell development and FAS apoptotic pathway leads to an abnormal lymphocytes survival with lymphoproliferation and secondarily affects B cells resulting in an antibody-mediated autoimmunity $(4,5,30,36,37)$.

Despite for IVIG, an immune-modulating mechanism has been proposed (38-40) in patients with secondary ES the resistance to therapy could be related to the persistence of longlived plasma cells secreting pathogenic autoantibodies resistant to immunomodulatory and B cell-depletion therapies (28). Our three patients with a secondary ES receiving Immunoglobulin Replacement Therapy all maintain good hematological control.

In this scenario, recent coming of Next Generation Sequencing (NGS) dramatically changed the diagnostic workup of ES. The rapid reduction in costs and analysis times of these techniques has made it possible to routinely apply them in the evaluation of the patients with ES. This helped clinicians to better characterize the genetic profile and pathological mechanisms of patients with PID with a nonspecific phenotype. In particular NGS target panels represent a powerful approach and could be really efficient when the diagnostic suspicion is relatively circumscribed while Whole Exome Sequencing find an application in conditions where the phenotype overlaps more than one PID. As recently reported in literature, these techniques have allowed finding many novel mutations in patients with PID associated with ES. In particular LRBA (Lipopolysaccharide-Responsive Beige-like an Anchor protein) and CTLA-4 (Cytotoxic T Lymphocyte Antigen-4) defects were described in patients with autoimmune cytopenias, lymphoproliferation, and humoral immune deficiency (41-44). LRBA colocalize in endosomal vesicles with CTLA-4 and its deficiency increases CTLA-4 turnover. CTLA4, upregulated in activated conventional $\mathrm{T}$ cells and constitutively expressed in
FoxP3+ regulatory ones, acts with a competitive mechanism with CD28 for binding B7 molecules (45). In patients with increased frequency of infections, autoimmune cytopenias and lymphoid hyperplasia these techniques allowed discovery a gain-of-function of PI-3-kinase, activated downstream of CD28 ligation and involved in B-cell proliferation and survival signaling $(45,46)$, or that of STAT3, involved in the suppression of Treg function and cytokine signaling $(45,47)$. Furthermore, thanks to Whole Exome Sequencing a homozygous mutation of TPP2, a postproteaosomal cytosolic protease, were found in 6 patients with early-onset Evans syndrome, respiratory infection, and developmental delay $(48,49)$. For some of these genetic mutations, targeted therapies with a reduced toxicity profile are under investigation for the opportunity of improving outcome (11).

Due to the rare nature of pediatric ES and refractory cytopenias, collaborative studies are necessary to investigate how each genetic mutation and specific pathogenetic mechanism is correlated to different clinical pictures. Thus, patients need to be included in national observational studies $(25,29,30)$ or ideally the cohort should be extended to an international perspective (www.sic-reg.org). This management could help us to determine a structured diagnostic algorithm, genetic tools and therapeutic strategies.

In conclusion in more than a half of our children, ES has been earliest manifestation of an underlying immune disorder, in particular when cytopenias were persistent-resistant to therapy, with early onset or associated with lymphadenopathy. We highlighted the importance of a proper laboratory-radiological investigation (Figure 1) and careful follow up of these patients in order to achieve a proper diagnosis and found the best therapeutic strategies. Further investigations are needed to understand the underlying immune dysregulation mechanisms, define markers of disease severity and the benefit-risk profile of second-line therapies.

\section{ETHICS STATEMENT}

Written informed consent for the publication of this retrospective paper were obtained from the parents.

\section{AUTHOR CONTRIBUTIONS}

$\mathrm{BR}$ and GP collected the data. BR and DZ analyzed the data and participated in writing the paper. $\mathrm{EF}, \mathrm{MC}, \mathrm{AM}, \mathrm{APr}$, and $\mathrm{APe}$ reviewed the article. All authors were involved in the clinical care of the patients, critically read the manuscript, approved the final version, and agreed to be accountable for all aspects of the work. 


\section{REFERENCES}

1. Evans RS, Takahashi K, Duane RT, Payne R, Liu C. Primary thrombocytopenic purpura and acquired hemolytic anemia; evidence for a common etiology. AMA Arch Intern Med. (1951) 87:48-65. doi: 10.1001/archinte.1951.03810010058005

2. Mathew P, Chen G, Wang W. Evans syndrome: results of a national survey. J Pediatr Hematol Oncol. (1997) 19:433-7. doi: 10.1097/00043426-199709000-00005

3. Wang WC. Evans syndrome in childhood: pathophysiology, clinical course, and treatment. J Pediatr Hematol Oncol. (1988) 10:330-8. doi: 10.1097/00043426-198824000-00013

4. Miano M. How I manage Evans syndrome and AIHA cases in children. $\mathrm{Br} J$ Haematol. (2016) 172:524-34. doi: 10.1111/bjh.13866

5. Mantadakis E, Farmaki E. Natural history, pathogenesis, and treatment of Evans syndrome in children. J Pediatr Hematol Oncol. (2017) 39:413-9. doi: 10.1097/MPH.0000000000000897

6. Fischer A, Provot J, Jais J-P, Alcais A, Mahlaoui N, Adoue D, et al. Autoimmune and inflammatory manifestations occur frequently in patients with primary immunodeficiencies. J Allergy Clin Immunol. (2017) 140:13881393.e8. doi: 10.1016/j.jaci.2016.12.978

7. Notarangelo LD. Primary immunodeficiencies (PIDs) presenting with cytopenias. Hematol Am Soc Hematol Educ Progr. (2009) 1:139-43. doi: 10.1182/asheducation-2009.1.139

8. Martínez-Valdez L, Deyà-Martínez A, Giner MT, Berrueco R, EsteveSolé A, Juan M, et al. Evans syndrome as first manifestation of primary immunodeficiency in clinical practice. J Pediatr Hematol Oncol. (2017) 39:490-4. doi: 10.1097/MPH.0000000000000880

9. Michel M, Chanet V, Dechartres A, Morin A-S, Piette J-C, Cirasino L, et al. The spectrum of Evans syndrome in adults: new insight into the disease based on the analysis of 68 cases. Blood. (2009) 114:3167-72. doi: 10.1182/blood-2009-04-215368

10. Teachey DT, Lambert MP. Diagnosis and management of autoimmune cytopenias in childhood. Pediatr Clin North Am. (2013) 60:1489-511. doi: $10.1016 /$ j.pcl.2013.08.009

11. Rotz SJ, Ware RE, Kumar A. Diagnosis and management of chronic and refractory immune cytopenias in children, adolescents, and young adults. Pediatr Blood Cancer. (2018) 65:e27260. doi: 10.1002/pbc.27260

12. Rodeghiero F, Stasi R, Gernsheimer T, Michel M, Provan D, Arnold $\mathrm{DM}$, et al. Standardization of terminology, definitions and outcome criteria in immune thrombocytopenic purpura of adults and children: report from an international working group. Blood. (2009) 113:2386-93. doi: 10.1182/blood-2008-07-162503

13. Bass GF, Tuscano ET, Tuscano JM. Diagnosis and classification of autoimmune hemolytic anemia. Autoimmun Rev. (2014) 13:560-4. doi: 10.1016/j.autrev.2013.11.010

14. Youinou P, Jamin C, Le Pottier L, Renaudineau Y, Hillion S, Pers J-O. Diagnostic criteria for autoimmune neutropenia. Autoimmun Rev. (2014) 13:574-6. doi: 10.1016/j.autrev.2014.01.001

15. Oliveira JB, Bleesing JJ, Dianzani U, Fleisher TA, Jaffe ES, Lenardo $\mathrm{MJ}$, et al. Revised diagnostic criteria and classification for the autoimmune lymphoproliferative syndrome (ALPS): report from the 2009 NIH International Workshop. Blood. (2010) 116:e35-e40. doi: 10.1182/blood-2010-04-280347

16. Cappelli S, Bellando Randone S, Martinović D, Tamas M-M, Pasalić K, Allanore Y, et al. "To be or not to be," 10 years after: evidence for mixed connective tissue disease as a distinct entity. Semin Arthritis Rheum. (2012) 41:589-98. doi: 10.1016/j.semarthrit.2011.07.010

17. Petri M, Orbai A-M, Alarcón GS, Gordon C, Merrill JT, Fortin PR, et al. Derivation and validation of the Systemic Lupus International Collaborating Clinics classification criteria for systemic lupus erythematosus. Arthritis Rheum. (2012) 64:2677-86. doi: 10.1002/art.3 4473

18. Lythgoe H, Morgan T, Heaf E, Lloyd O, Al-Abadi E, Armon K, et al. Evaluation of the ACR and SLICC classification criteria in juvenile-onset systemic lupus erythematosus: a longitudinal analysis. Lupus. (2017) 26:1285-90. doi: 10.1177/09612033177 00484
19. Teachey DT. Unmasking Evans syndrome: T-cell phenotype and apoptotic response reveal autoimmune lymphoproliferative syndrome (ALPS). Blood. (2005) 105:2443-8. doi: 10.1182/blood-2004-09-3542

20. Seif AE, Manno CS, Sheen C, Grupp SA, Teachey DT. Identifying autoimmune lymphoproliferative syndrome in children with Evans syndrome: a multi-institutional study. Blood. (2010) 115:2142-5. doi: 10.1182/blood-2009-08-239525

21. Bleesing JJH. Immunophenotypic profiles in families with autoimmune lymphoproliferative syndrome. Blood. (2001) 98:2466-73. doi: 10.1182/blood.V98.8.2466

22. Lougaris V, Facchini E, Baronio M, Lorenzini T, Moratto D, Specchia F, et al. Progressive severe B cell deficiency in pediatric Rubinstein-Taybi syndrome. Clin Immunol. (2016) 173:181-3. doi: 10.1016/j.clim.2016.10.019

23. Pieper K, Rizzi M, Speletas M, Smulski CR, Sic H, Kraus H, et al. A common single nucleotide polymorphism impairs B-cell activating factor receptor's multimerization, contributing to common variable immunodeficiency. $J$ Allergy Clin Immunol. (2014) 133:1222-5. doi: 10.1016/j.jaci.2013.11.021

24. Pui C-H, Wilimas J, Wang W. Evans syndrome in childhood. J Pediatr. (1980) 97:754-8. doi: 10.1016/S0022-3476(80)80258-7

25. Aladjidi $N$, Fernandes $H$, Leblanc $T$, Vareliette A, Rieux-Laucat $F$, Bertrand Y, et al. Evans syndrome in children: long-term outcome in a prospective French National Observational Cohort. Front Pediatr. (2015) 3:79. doi: $10.3389 /$ fped.2015.00079

26. Al Ghaithi I, Wright NAM, Breakey VR, Cox K, Warias A, Wong T, et al. Combined autoimmune cytopenias presenting in childhood. Pediatr Blood Cancer. (2016) 63:292-8. doi: 10.1002/pbc.25769

27. Antoon JW, Metropulos D, Joyner BL. Evans syndrome secondary to common variable immune deficiency. J Pediatr Hematol Oncol. (2016) 38:243-5. doi: 10.1097/MPH.0000000000000550

28. Ghosh S, Seidel MG. Editorial: current challenges in immune and other acquired cytopenias of childhood. Front Pediatr. (2016) 4:3. doi: 10.3389/fped.2016.00003

29. Sipurzynski J, Fahrner B, Kerbl R, Crazzolara R, Jones N, Ebetsberger $\mathrm{G}$, et al. Management of chronic immune thrombocytopenia in children and adolescents: lessons from an Austrian national crosssectional study of 81 patients. Semin Hematol. (2016) 53:S43-S47. doi: 10.1053/j.seminhematol.2016.04.013

30. Aladjidi N, Leverger G, Leblanc T, Picat MQ, Michel G, Bertrand Y, et al. New insights into childhood autoimmune hemolytic anemia: a French national observational study of 265 children. Haematologica. (2011) 96:65563. doi: 10.3324/haematol.2010.036053

31. Rensing-Ehl A, Warnatz K, Fuchs S, Schlesier M, Salzer U, Draeger $\mathrm{R}$, et al. Clinical and immunological overlap between autoimmune lymphoproliferative syndrome and common variable immunodeficiency. Clin Immunol. (2010) 137:357-65. doi: 10.1016/j.clim.2010.08.008

32. Rao VK, Price S, Perkins K, Aldridge P, Tretler J, Davis J, et al. Use of rituximab for refractory cytopenias associated with autoimmune lymphoproliferative syndrome (ALPS). Pediatr Blood Cancer. (2009) 52:84752. doi: $10.1002 /$ pbc. 21965

33. Rao VK, Oliveira JB. How I treat autoimmune lymphoproliferative syndrome. Blood. (2011) 118:5741-51. doi: 10.1182/blood-2011-07-325217

34. Wang W, Herrod H, Pui C-H, Presbury G, Wilimas J. Immunoregulatory abnormalities in evans syndrome. Am J Hematol. (1983) 15:381-90. doi: 10.1002/ajh.2830150409

35. Karakantza M, Mouzaki A, Theodoropoulou M, Bussel JB, Maniatis A. Th1 and Th2 cytokines in a patient with Evans' syndrome and profound lymphopenia. Br J Haematol. (2000) 110:968-70. doi: 10.1046/j.1365-2141.2000.02296.x

36. Farruggia P, Dufour C. Diagnosis and management of primary autoimmune neutropenia in children: insights for clinicians. Ther Adv Hematol. (2015) 6:15-24. doi: 10.1177/2040620714556642

37. Seidel MG. Autoimmune and other cytopenias in primary immunodeficiencies: pathomechanisms, novel differential diagnoses, and treatment. Blood. (2014) 124:2337-44. doi: 10.1182/blood-2014-06583260

38. Anthony RM, Kobayashi T, Wermeling F, Ravetch JV. Intravenous gammaglobulin suppresses inflammation through a novel T H 2 pathway. Nature. (2011) 475:110-4. doi: 10.1038/nature10134 
39. Nagelkerke SQ, Dekkers G, Kustiawan I, van de Bovenkamp FS, Geissler J, Plomp R, et al. Inhibition of Fc $\gamma$ R-mediated phagocytosis by IVIg is independent of IgG-Fc sialylation and Fc $\gamma$ RIIb in human macrophages. Blood. (2014) 124:3709-18. doi: 10.1182/blood-2014-05-576835

40. Burns JC, Franco A. The immunomodulatory effects of intravenous immunoglobulin therapy in Kawasaki disease. Expert Rev Clin Immunol. (2015) 11:819-25. doi: 10.1586/1744666X.2015.1044980

41. Kuehn HS, Ouyang W, Lo B, Deenick EK, Niemela JE, Avery DT, et al. Immune dysregulation in human subjects with heterozygous germline mutations in CTLA4. Science. (2014) 345:1623-7. doi: $10.1126 /$ science. 1255904

42. Schubert D, Bode C, Kenefeck R, Hou TZ, Wing JB, Kennedy A, et al. Autosomal dominant immune dysregulation syndrome in humans with CTLA4 mutations. Nat Med. (2014) 20:1410-6. doi: 10.1038/nm.3746

43. Revel-Vilk S, Fischer U, Keller B, Nabhani S, Gámez-Díaz L, RensingEhl A, et al. Autoimmune lymphoproliferative syndrome-like disease in patients with LRBA mutation. Clin Immunol. (2015) 159:84-92. doi: 10.1016/j.clim.2015.04.007

44. Besnard C, Levy E, Aladjidi N, Stolzenberg M-C, Magerus-Chatinet A, Alibeu O, et al. Pediatric-onset Evans syndrome: heterogeneous presentation and high frequency of monogenic disorders including LRBA and CTLA4 mutations. Clin Immunol. (2018) 188:52-7. doi: 10.1016/j.clim.2017. 12.009

45. Grimbacher B, Warnatz K, Yong PFK, Korganow A. The crossroads of autoimmunity and immunodeficiency : lessons from polygenic traits and monogenic defects. J Allergy Clin Immunol. (2017) 137:3-17. doi: 10.1016/j.jaci.2015.11.004
46. Lucas CL, Kuehn HS, Zhao F, Niemela JE, Deenick EK, Palendira U, et al. Dominant-activating germline mutations in the gene encoding the $\mathrm{PI}(3) \mathrm{K}$ catalytic subunit p110 $\delta$ result in $\mathrm{T}$ cell senescence and human immunodeficiency. Nat Immunol. (2014) 15:88-97. doi: 10.1038/ni.2771

47. Milner JD, Vogel TP, Forbes L, Ma CA, Stray-Pedersen A, Niemela JE, et al. Early-onset lymphoproliferation and autoimmunity caused by germline STAT3 gain-of-function mutations. Blood. (2015) 125:591-9. doi: 10.1182/blood-2014-09-602763

48. Lu W, Zhang Y, McDonald DO, Jing H, Carroll B, Robertson N, et al. Dual proteolytic pathways govern glycolysis and immune competence. Cell. (2014) 159:1578-90. doi: 10.1016/j.cell.2014.12.001

49. Stepensky P, Rensing-Ehl A, Gather R, Revel-Vilk S, Fischer U, Nabhani $\mathrm{S}$, et al. Early-onset Evans syndrome, immunodeficiency, and premature immunosenescence associated with tripeptidyl-peptidase II deficiency. Blood. (2015) 125:753-61. doi: 10.1182/blood-2014-08-593202

Conflict of Interest Statement: The authors declare that the research was conducted in the absence of any commercial or financial relationships that could be construed as a potential conflict of interest.

Copyright (c) 2019 Rivalta, Zama, Pancaldi, Facchini, Cantarini, Miniaci, Prete and Pession. This is an open-access article distributed under the terms of the Creative Commons Attribution License (CC BY). The use, distribution or reproduction in other forums is permitted, provided the original author(s) and the copyright owner(s) are credited and that the original publication in this journal is cited, in accordance with accepted academic practice. No use, distribution or reproduction is permitted which does not comply with these terms. 